\section{Genetic Resources of Apricots (Prunus armeniaca L.) in Central Asia}

\author{
David E. Zaurov and Thomas J. Molnar ${ }^{1}$ \\ Department of Plant Biology and Pathology, School of Environmental and \\ Biological Sciences, Rutgers University, 59 Dudley Road, New Brunswick, \\ NJ 08901-8520
}

\author{
Sasha W. Eisenman \\ Department of Landscape Architecture and Horticulture, School of \\ Environmental Design, Temple University, 580 Meetinghouse Road, Ambler, \\ PA 19002-3923
}

Timothy M. Ford

Improving Perennial Plants for Food and Bio-energy, Inc., 400 North 1000 East, Hyde Park, UT 84318

Ravza F. Mavlyanova

Uzbek Scientific Research Institute of Plant Industry, 702133, P.O. Botanika, Kibray District, Tashkent Province, Uzbekistan

John M. Capik

Department of Plant Biology and Pathology, School of Environmental and Biological Sciences, Rutgers University, 59 Dudley Road, New Brunswick, NJ 08901-8520

\section{Reed Funk}

Department of Plant Biology and Pathology, School of Environmental and Biological Sciences, Rutgers University, 59 Dudley Road, New Brunswick, NJ 08901-8520; and Improving Perennial Plants for Food and Bio-energy, Inc., 400 North 1000 East, Hyde Park, UT 84318

\section{Joseph C. Goffreda}

Department of Plant Biology and Pathology, School of Environmental and Biological Sciences, Rutgers University, 59 Dudley Road, New Brunswick, NJ 08901-8520

Additional index words. Armeniaca armeniaca, fruit crops, germplasm collection, Prunus dasycarpa, tree breeding

Abstract. Central Asia is a center of diversity for many important fruit and nut tree species, including wild and cultivated apricots (Prunus armeniaca L.). A wealth of apricot germplasm that expresses novel and valuable characteristics such as fruits with high soluble solids, edible kernels, glabrous skin, and diverse colors and flavors, as well as later-blooming flowers, late-maturing fruit, and drought, cold, and salt tolerance, can be found growing across this region. Since the dissolution of the Soviet Union, Central Asia has become more accessible for reciprocal germplasm exchange and scientific collaborations. Thus, opportunities now exist to obtain, study, and use a much wider diversity of Central Asian apricot germplasm in breeding efforts, which can lead to improved crop traits and ultimately an expansion of the regions where this high-value crop can be grown. To bring attention to the valuable $P$. armeniaca genetic resources found in Central Asia and to promote its better use, management, and preservation, a description and history of the species from a Central Asian perspective, along with recent and ongoing activities, are discussed in this article.

Central Asia is a center of origin for many important fruit and nut tree species, including wild and cultivated apricots (Prunus armeniaca) (Vavilov, 1931, 1951). Apricots, considered by many to be one of the most delicious tree fruits, have been produced and appreciated in the region for millennia and are intertwined with the culture. Today, Uzbekistan is the third largest producer of apricots in fruit maturation; and drought, salt, cold, and disease tolerance (Mirzaev, 2000; Mirzaev and Kuznetsov, 1984; Ribakov and Ostroukhova, 1972). Despite this rich genetic diversity, geographical and political isolation-in conjunction with recent plant quarantine and importation restrictions - have limited access to Central Asian germplasm in Western research and genetic improvement efforts. This limited access is unfortunate, because germplasm from Central Asia can be used to improve many aspects of apricot culture, as shown in the work of Ledbetter (2009) and Ledbetter et al. (2006) regarding sugar profiles of the fruit. More extensive use of these genetic resources could lead to enhanced adaptation and, ultimately, the expansion of regions where this high-value, sustainable, and healthy crop could be grown.

Two apricot species, $P$. armeniaca and $P$. dasycarpa Ehrh., can be found naturally occurring in Central Asia (Mirzaev, 2000). Prunus armeniaca [synonyms: Armeniaca armeniaca (L.) Huth, A. vulgaris Lam., $P$. tiliifolia Salisb.], referred to as the common apricot, is a deciduous, temperate tree ranging from 5 to $15 \mathrm{~m}$ tall. It produces the wellknown apricot fruits, some with edible kernels, that vary tremendously in size, shape, color, and flavor. It can be found growing up to $3000 \mathrm{~m}$ above sea level in natural stands as well as cultivated plantings across Central Asia, northwest China, Afghanistan, Kashmir, parts of Iran, Dagestan (Russia), Turkey, and the Caucasus region.

Prunus dasycarpa [synonyms: A. atropurpurea Loisel., A. dasycarpa (Ehrh.) Borkh., A. fusca Turpin \& Poit., P. armeniaca var. dasycarpa (Ehrh.) K.Koch, P. nigra Desf.], commonly referred to as the black apricot, is reported to be a hybrid of $P$. armeniaca and $P$. cerasifera Ehrh. (cherry plum) (Zhukovsky, 1971). It grows as a small tree and is typically found in regions where the two species are sympatric. It is cultivated in Central Asia, the state of Jammu and Kashmir in India, the Beluchistan region of Pakistan, and in the Xinjiang Province of China. Its fruits differ from that of $P$. armeniaca by being generally small with purple skin and yellow flesh.

The focus of this article is on the genetic resources of wild and cultivated $P$. armeniaca in Central Asia, a region Vavilov $(1931,1951)$ considered to be one of the centers of origin of the species. It should be noted, however, that in Vavilov's system of describing the centers of origin of crop plants, the "Central Asiatic Center of Origin" included Northwest India [Punjab, the northwestern frontier provinces (current-day Pakistan), and Kashmir], Afghanistan, Tajikistan, Uzbekistan, and the western Tian Shan Mountains (Kyrgyzstan and Xinjiang, China). The highlands of Turkmenistan were part of the "Near-Eastern Center of Origin." This article covers only Uzbekistan, Tajikistan, Turkmenistan, Kyrgyzstan, and part of southern Kazakhstan (Fig. 1). Across this vast region exist native populations and locally derived cultivars that are adapted to a wide variety of climatic conditions and soil types. The climate and soils of 
Table 1. Top 20 apricot (Prunus armeniaca) producing countries and Central Asian countries (in bold). Total estimated production in 2011 from greatest to least, and area harvested (FAO, 2013).

\begin{tabular}{lccc}
\hline Country & Production (t) & Area harvested (ha) & Avg harvest per hectare (t.ha $\left.{ }^{-1}\right)$ \\
\hline Turkey & 676,138 & 59,696 & 11.3 \\
Iran (Islamic Republic of) & 452,988 & 50,177 & 9.0 \\
Uzbekistan & $\mathbf{3 5 6 , 0 0 0}$ & $\mathbf{3 6 , 5 0 0}$ & $\mathbf{9 . 8}$ \\
Italy & 263,132 & 19,595 & 13.4 \\
Algeria & 205,000 & 32,000 & 6.4 \\
Pakistan & 189,420 & 29,634 & 6.4 \\
France & 154,980 & 13,902 & 11.1 \\
Morocco & 132,523 & 12,678 & 10.5 \\
Ukraine & 119,900 & 9,300 & 12.9 \\
Japan & 106,900 & 16,600 & 6.4 \\
Egypt & 96,643 & 6,247 & 15.5 \\
China & 88,010 & 24,000 & 3.7 \\
Spain & 86,889 & 18,727 & 4.6 \\
Greece & 82,800 & 6,000 & 13.8 \\
Syrian Arab Republic & $\mathbf{7 5 , 9 1 9}$ & 13,746 & 5.5 \\
United States of America & 60,509 & 4,917 & 12.3 \\
Russian Federation & 60,000 & 1,000 & 5.5 \\
South Africa & 57,421 & 6,300 & 9.1 \\
Afghanistan & 56,043 & 8,320 & 6.7 \\
Turkmenistan (21st) & $\mathbf{3 6 , 0 9 1}$ & $\mathbf{2 , 3 5 3}$ & $\mathbf{1 5 . 3}$ \\
Tajikistan (25th) & $\mathbf{2 5 , 0 0 0}$ & $\mathbf{1 1 , 0 0 0}$ & $\mathbf{2 . 3}$ \\
Kyrgyzstan (32nd) & $\mathbf{1 8 , 2 0 0}$ & $\mathbf{8 , 0 0 0}$ & $\mathbf{2 . 3}$ \\
Kazakhstan (37th) & $\mathbf{1 3 , 0 0 0}$ & $\mathbf{2 , 6 3 2}$ & $\mathbf{4 . 9}$ \\
\hline
\end{tabular}

the Central Asian region vary considerably depending on geographic location, altitude, and exposure. The majority of the region has a sharp continental climate and displays distinct seasonal changes with occasional wide daily temperature fluctuations. The average monthly air temperature across Central Asia varies from 24.0 to $27.7^{\circ} \mathrm{C}$ in July to -0.3 to $3.5^{\circ} \mathrm{C}$ in January. The maximum air temperature in some locations can reach as high as $48{ }^{\circ} \mathrm{C}$ with low temperatures to $-40{ }^{\circ} \mathrm{C}$. In November and December as well as in February and March, air temperature may fluctuate from -25 to $25^{\circ} \mathrm{C}$ within a 24-h period (Mirzaev, 2000). Precipitation is also variable, from 87 to $366 \mathrm{~mm}$ in the valleys (apricot cultivation in these areas requires irrigation) to over $1000 \mathrm{~mm}$ in areas of higher elevation (Mirzaev, 2000). The major soils found in the valley regions are generally of the sierozem type (from light to dark, typically with a $\mathrm{pH}$ of 8.1 to 8.2) and in the higher elevations soils range from a dark sierozem to brown soil type with a $\mathrm{pH}$ of 7.8 to 8.0 at $1100 \mathrm{~m}$ above sea level and 7.6 to 8.0 at $1600 \mathrm{~m}$ above sea level (Mirzaev, 1982). Most apricot cultivation occurs in regions where the soils are classified as the various types of sierozem (light, typical,

\footnotetext{
Received for publication 19 Feb. 2013. Accepted for publication 2 May 2013.

We acknowledge the New Jersey Agricultural Experiment Station and the Rutgers Center for Turfgrass Science for their support. We are also grateful to the late Prof. Uri M. Djavacynce (Schroeder Institute, Uzbekistan), Academician Djamin Akimaliev (Kyrgyz Agricultural Institute), Professor Ishembay Sodembekov (Kyrgyz Agrarian University named after K.I. Skryabin), Dr. Arstanbek Kuliev, and Mrs. Aisha Turbatova (Gareev Botanical Garden, Kyrgyzstan) for their manuscript contributions and/or assistance in the collection of apricot germplasm.

${ }^{1}$ To whom reprint requests should be addressed; e-mailmolnar@aesop.rutgers.edu.
}

dark). These soils are typically non-saline [total salts less than $0.25 \%$ and chlorine less than $0.01 \%$ of absolute dry weight (ADS) of soil] or slightly saline (total salts less than $0.25 \%$ to $0.5 \%$ and chlorine less than $0.01 \%$ to $0.04 \%$ of ADS) with organic matter content ranging from $1 \%$ to $4 \%$. To a lesser degree, apricots are also cultivated on the brown and light brown carbonated soils found in the foothill and mountain areas (Pankov, 1965).

The growing range of apricot in Central Asia reaches its northern limit at $45^{\circ} \mathrm{N}$ latitude (Zhukovsky, 1971). In mountain forests, wild trees can be found with small, sweet fruits that often have small leaves and bitter kernels (Kudryashov, 1950; Lomakin, 1971; Zhukovsky, 1971). They occur up to $1500 \mathrm{~m}$ above sea level in the western Tian Shan Mountain System, on the south slopes of the Chatkal (Fig. 1, no. 1), Uzun-Akhmat (Fig. 1, no. 2), and Susamir Mountain Ranges (Fig. 1, no. 3); on the northwest slopes of the Ferghana Range (Fig. 1, no. 4); and on the Zailiysky and Dzhungarsky Alatau Mountains (Fig. 1, nos. 5 and 6 , respectively). Native trees can also be found in the Kotur-Bulak Gorge, in Almaty Province, Kazakhstan (Bailey and Hough, 1975; Kalmikov, 1973; Mehlenbacher et al., 1991; Mirzaev, 2000; Mirzaev and Kuznetsov, 1984; Zhukovsky, 1971). In addition, wild and cultivated apricots can be found in the Pamir Mountains (Fig. 1, no. 7) at elevations of more than $3000 \mathrm{~m}$ (Pulatov, 1976).

In the 1980s, apricot orchards covered more than 83,000 ha in Central Asia: 43,600 ha in Uzbekistan, 22,600 ha in Tajikistan, 10,300 ha in Kyrgyzstan, and 6,500 ha in Turkmenistan (Mirzaev and Kuznetsov, 1984). Today, the total production area reported has decreased to $\approx 60,500$ ha, although 36,500 ha can now be found in Uzbekistan (Table 1) (FAO, 2013).

Kostina (1936, 1941, 1964) divided the world's apricot germplasm into four ecogeographical groups based on geographic origin and morphological characteristics: Central
Asian, Irano-Caucasian, European, and Dzhungar-Zaili. An overview of Kostina's ecogeographical groups and discussion on the migration and domestication of apricot germplasm from its centers of origin can be found in Zhebentyayeva et al. (2012). Of these groups, the Central Asian group is considered to be the largest and most diverse. Apricot cultivars in Central Asia largely originate from wild plants found in the region with the total number of cultivars recorded exceeding 500 (Andrienko, 1997; Esenbaev et al., 1981; Kostina, 1978; Mirzaev, 2000; Mirzaev and Kuznetsov, 1984).

When compared with the other ecogeographical groups, the Central Asian group has been reported to possess the most heat- and cold-resistant and salt-tolerant forms of the species as well as forms expressing a wide variety of fruit characteristics (Ivanov and Ivanova, 1981; Kostina, 1936; Mirzaev, 2000; Mirzaev and Kuznetsov, 1984; Ribakov and Ostroukhova, 1972; Zhebentyayeva et al., 2003; Zhukovsky, 1971). For example, studies were performed in Tajikistan with 68 apricot cultivars from different ecogeographical groups, including European cultivars. Results showed the Central Asian cultivars were the most coldhardy, led by Mirsandjali \#2, Khurmai, Novot, Kandak, Gulyangi-52, Ubileini Navoi, Iskandari, and others (Usmanov, 1983). Researchers in the Ukraine conducted a similar study over a 5-year period (2004-08). They looked at cold tolerance of 60 cultivars from Armenia, Bulgaria, Hungary, China, the United States, Moldova, Romania, Uzbekistan, Czech Republic, and others, and again showed that the most cold-hardy apricot cultivars were of Central Asian origin (Korzin and Gorina, 2009). A third study in Uzbekistan also demonstrated that Central Asian apricot cultivars have greater overall heat and cold resistance in comparison with other ecogeographical groups when tested in Uzbekistan (Mirzaev, 2000; Mirzaev and Kuznetsov, 1984).

Central Asian cultivars were also reported to have higher fruit yields and sugar content and were considered to have superior flavor and fruit coloring compared with many other cultivars (Ribakov and Ostroukhova, 1972; Usmanov, 1983).

Trees from within the Central Asian group are generally characterized as being selfincompatible and are adapted to a wide array of soil types (Mirzaev, 2000). Zhebentyayeva et al. (2003) suggested that the great diversity of apricots found in the region is likely the result of domestication occurring over millennia through the natural association of wild and partly domesticated forms and their intercrossing with cultivated germplasm that originated in the Ferghana Valley. Maghuly et al. (2005) included a number of Central Asian cultivars in their simple sequence repeat (SSR) study and confirmed that they represent a basal lineage. They also exhibited high variability in a number of different alleles, further supporting the increased level of genetic diversity present in the Central Asian germplasm. The highly mountainous, 


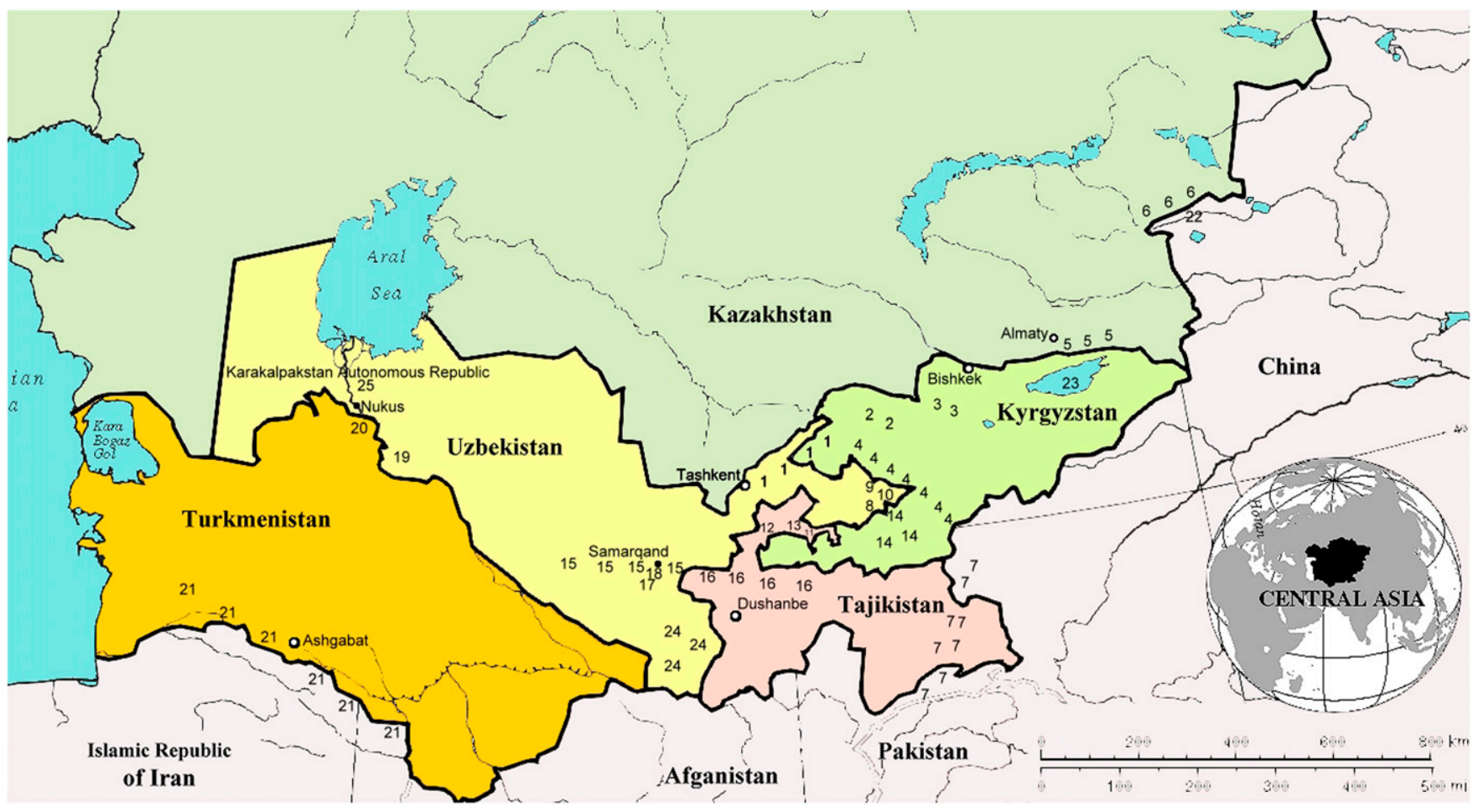

Fig. 1. Map of Central Asia including reference to locations mentioned in the text in the order they are mentioned. Country names are abbreviated: Uzbekistan (Uzb.), Tajikistan (Taj.), Kyrgyzstan (Kyr.), Turkmenistan (Tur.). (1) Chatkal Mountain Range; (2) Uzun-Akhmat Mountain Range; (3) Susamir Mountain Range; (4) Ferghana Mountain Range; (5) Zailiysky Mountain Range; (6) Dzhungarsky Alatau Mountains; (7) Pamir Mountains; (8) Ferghana Province, Uzb.; (9) Namangan Province, Uzb.; (10) Andijan Province, Uzb.; (11) Isfara, Taj.; (12) Khudjan, Taj.; (13) Kanibadam, Taj.; (14) Osh Province, Kyrgyzstan; (15-16) Zarafshan River Valley (Samarqand Province and the upper and lower reaches of the Zarafshan River in Bukhara Province, Uzb. and adjacent western Taj.); (17) Shakhrisabz region, Uzb.; (18) Kitab region, Uzb.; (19) Khorezm Province, Uzb.; (20) Daşoguz (Tashauz) Province, Tur.; (21) Kopet-Dag Range, Tur.; (22) Xinjiang region, China; (23) Issyk Kul region, Kyr.; (24) Dinau, Surkhandaryo Province, Uzb.; and (25) Chimbay, Karakalpakstan Autonomous Republic.

isolated terrain, the self-incompatible nature of the apricots found there, the ancient trade routes through Central Asia, and the early propagation of orchards through seed (not through clonal means) all support this hypothesis.

Kostina further divided the Central Asia ecogeographical group into five subgroups (Ferghana, Zarafshan, Shakhrisabz, Khorezm, and Kopet-Dag) with the Ferghana and Zarafshan subgroups being the most significant in size and diversity of germplasm. Much more recently, this division was supported by SSR analysis performed on a wide collection of $P$. armeniaca held at the Nikita Botanical Gardens in Yalta, Ukraine (Zhebentyayeva et al., 2003).

To provide examples of the diversity of locally derived apricot germplasm and the sometimes extreme environment in which it is grown, the geographic and climatic conditions of Kostina's Central Asian ecogeographical subgroups are discussed subsequently. An overview of the apricot germplasm found in each group is provided as well.

Ferghana subgroup. The Ferghana ecogeographical subgroup is the largest, most diverse, and well studied of the Central Asian subgroups, in part because more than $65 \%$ of the apricot orchards in Central Asia are located in the Ferghana Valley (Mirzaev, 2000). The Valley spans the Ferghana, Namangan, and Andijan Provinces of Uzbekistan (Fig. 1, nos. 8,9 , and 10 , respectively), part of northern Tajikistan [area surrounding the Isfara, Khudjan, and Kanibadam regions (Fig. 1, nos. 11, 12, and 13, respectively)], and a small region in the Osh Province of Kyrgyzstan (Fig. 1, no. 14).

Apricot cultivation in Ferghana Province, Uzbekistan, occurs in the Kokand and Ferghana regions. The Kokand production region occurs at an elevation of 400 to $500 \mathrm{~m}$ above sea level and is typically very windy. Its average yearly precipitation is 80 to $130 \mathrm{~mm}$ and it has 205 to 209 frost-free days. Soils in the region are alluvial and are classified as being light-sierozem (stony clay-loam, $0.8 \%$ to $1.2 \%$ organic matter) to light-meadow ( $2.5 \%$ to $4 \%$ organic matter) types and are non-saline or slightly saline. Irrigation water for production comes from the Syr Darya, Sokh, and Isfara Rivers. Like the Kokand production region, the Ferghana region also occurs at an elevation of 400 to $500 \mathrm{~m}$ above sea level, but it has a higher yearly precipitation (140-180 $\mathrm{mm}$ ) and more frost-free days (typically $\approx 212 \mathrm{~d}$ ). Soils in the Ferghana region are classified as non-saline sierozem, slightly saline meadow-type, and stony lightsierozem soils. Orchards are irrigated from the Syr Darya River and a number of other small rivers originating in the Alai Mountain Range. The Kokand and Ferghana regions also have higher elevation growing zones (700$1700 \mathrm{~m}$ above sea level), which have similar yearly precipitation $(180-350 \mathrm{~mm})$ and frostfree days (196-206). The main soil type in the higher elevation growing zone is sierozem ( $1.5 \%$ to $2.5 \%$ organic matter) with clay and sandy-loam areas. Irrigation water comes from the Sokh and Shakhimardan Rivers.

Apricot production in Namangan Province, Uzbekistan, occurs at an elevation of 400 to $800 \mathrm{~m}$ above sea level. This is the one of the warmest locations in Uzbekistan and it has an average yearly precipitation of 170 to $180 \mathrm{~mm}$ with 229 frost-free days. The soils are non-saline or slightly saline and are categorized as a typical sierozem and highclay, light-meadow type. The Syr Darya River and other small rivers from the Chatkal Range are the primary sources of irrigation water. Apricots are also grown in this province at higher elevations (700-1000 $\mathrm{m}$ above sea level) where an average of 135 to $350 \mathrm{~mm}$ of annual precipitation and 219 frost-free days occur. The soils are typically of the sierozem type (Mirzaev, 2000; Mirzaev and Kuznetsov, 1984; Pankov, 1965).

Apricot production in Andijan Province, Uzbekistan, occurs at an elevation 400 to $1200 \mathrm{~m}$ above sea level. This production area has an average of 200 to $400 \mathrm{~mm}$ of yearly precipitation and 193 to 217 frost-free days. The soils are non-saline, of the typical sierozem and light-meadow type, or are stony, shallow, slightly saline, dark-sierozem with the organic matter content ranging from $2.5 \%$ to $4 \%$ (Babushkin, 1963; Kolosova, 1981; Mirzaev, 2000; Mirzaev and Kuznetsov, 1984; Pankov, 1965).

Apricot production in northern Tajikistan occurs in the regions surrounding Isfara, 
Khudjan, and Kanibadam (part of the Ferghana Valley), where the mean yearly temperature is $13.6^{\circ} \mathrm{C}$. Hot summers occur in this region with a mean temperature in July of $27.6{ }^{\circ} \mathrm{C}$ with days occasionally reaching as high as $43{ }^{\circ} \mathrm{C}$. The average yearly precipitation varies from $200 \mathrm{~mm}$ in the valleys to greater than $600 \mathrm{~mm}$ in the foothills. The relative air humidity in the summer is $27 \%$ to $30 \%$. The winter is mild with a mean January temperature of $-1.3{ }^{\circ} \mathrm{C}$. The soils are light brown and have low organic matter content (Dzhuraev and Pulatov, 1988; Usmanov, 1983).

Apricot cultivars and accessions from the Ferghana subgroup are generally characterized as producing fruits with an elongated shape that are slightly or moderately pubescent. Externally, the fruits are orange or creamy yellow and sometimes have a slight reddish blush. The flesh is dense and has a high total sugar content and low acidity. The major end use of apricots from this subgroup is dried fruit with only $\approx 5 \%$ used for fresh consumption. The cultivars that are used for fresh fruit consumption are specifically earlyor late-maturing. Rare glabrous, white-fleshed, juicy forms can also be found in this subgroup (Mirzaev, 2000; Mirzaev and Kuznetsov, 1984).

It should be mentioned, although cultivars are typically propagated clonally in this region, seed propagation has occurred, which adds some confusion regarding cultivar names and identities. To help organize the wide diversity of apricot germplasm in the region, cultivars have been grouped according to common morphological and phenological characteristics and geographic origins, although not every cultivar fits into a specific group. These groupings are referred to as sortotypes, or conculta, of which more than 30 have been described with each sortotype containing many cultivars. Despite the wide phenotypic diversity, the most commonly grown cultivars fall into a small number of sortotypes across the region. In many instances, the most important cultivar of the sortotype shares its name with the sortotype with the other cultivars in the group containing some derivation of the sortotypes name. For example, the most commonly grown cultivars of the Ferghana subgroup are Babai, Isfarak, Kandak, Hurmai, Mirsandjali, and Supkhani, which are described in Table 2.

The Babai sortotype holds $\approx 20$ cultivars, which are known for retaining fruit in windy conditions and have high sugar content. The Isfarak sortotype holds 25 cultivars and is known for dried fruit production. The Kandak sortotype holds 17 cultivars and is noted for some retention of fruits in windy conditions. The Hurmai sortotype holds more than 40 cultivars characterized as having large size fruit and tolerance to a wide variety of soil conditions. The Mirsandjali sortotype holds 16 cultivars and is used for dried and canned end-use purposes. The Supkhani sortotype holds 15 cultivars that typically produce large fruits and are widely distributed in Central Asia. Cultivars in the Isfarak and Supkhani sortotypes are also known for having higher soil and management requirements when compared with Hurmai (Mirzaev, 2000; Mirzaev and Kuznetsov, 1984; Smirnova, 1980).

Another notable cultivar is the very latematuring Kech Pishar, which does not fall into a specific sortotype. The fruits mature around the end of August to mid-September. Other notable cultivars that do not fit into a sortotype classification include the glabrous, white-fleshed Ak uryuk (Table 2), Dzhaupazak, and Lyuchak, which are grown mostly for fresh fruit.

Zarafshan subgroup. This subgroup is found in the Zarafshan River Valley located in Uzbekistan (Samarqand Province and the upper and lower reaches of the Zarafshan River in Bukhara Province) and in adjacent western Tajikistan (Fig. 1, nos. 15 and 16, respectively). In Samarqand Province, Uzbekistan, apricot cultivation occurs at an elevation of 200 to $1000 \mathrm{~m}$ above sea level. This area has an average annual precipitation of 200 to $400 \mathrm{~mm}$ and 170 to 216 frost-free days. Orchards are generally irrigated and the soils are classified as sierozem and can be clay or sandy-loam. In Bukhara Province, Uzbekistan, apricot cultivation occurs at 200 to $500 \mathrm{~m}$ above sea level. This area has an average annual precipitation of only 110 to $120 \mathrm{~mm}$ and 217 frost-free days. The soils are of the sierozem and meadow-type with moderate salinity. The Zarafshan River is the source of water for irrigation in both Provinces (Mirzaev and Kuznetsov, 1984). In the upper Zarafshan Valley region of Tajikistan, apricots are grown from 600 to $2000 \mathrm{~m}$ above sea level (Pulatov, 1976). Yearly precipitation ranges from 110 to $400 \mathrm{~mm}$ and soils in this area are generally classified as sierozem with those above $1600 \mathrm{~m}$ classified as brown soils.

Although smaller in size compared with the Ferghana subgroup, the Zarafshan subgroup is considered more variable in fruit size, color, and flavor (Mirzaev, 2000; Mirzaev and Kuznetsov, 1984). Achkinazi (1933) divided all of the cultivars of this subgroup into six categories depending on time of maturation, fruit size, and the ability of the fruit to dry on the tree. These include 'Dzhaupazak' (earlymaturing), 'Makhtoba' (light-colored fruit), 'Rukhi djuvanon miona' (late-blooming), 'Arzami' (intense exterior color with carminered blush), 'Gulyangi' (fruits are persistent and dry on the tree; this type is found around the upper Zarafshan River), and 'Kandak' (high sugar content). In general, fruits from this subgroup are used for producing dried apricots as well as for fresh consumption and canning. Some cultivars within this subgroup, particularly those grown near the city of Samarqand, are glabrous with white or light-colored flesh and relatively high acidity. These include 'Arzami pozdniy', 'Gulungi luchak', and 'Makhtobi samarqandsky'. The most widely grown cultivars in this subgroup include Kursadik (Table 2), Arzami (Table 2), Ahrori, Rukhi djuvanon miona, Gulungi luchak, Luchak zolotistyi, Badaminskiy krupnoplodniy, and Mokhtobi samarqandskiy. More recently developed cultivars include Ubileini Navoi (Table 2; recommended for irrigated valleys and the lower reaches of the mountains), Zarafshanskiy pozdniy (recommended for a broad testing in the all regions), Novvot (resistant to frost and disease; recommended for the foothill and mountain zones), Oleg Koshevoy (Table 2; recommended for the backyards in the southwest part of Uzbekistan), and Samarqandskiy ranniy \#117 (used for multiple end uses) (Mirzaev, 2000).

After extensive testing of cultivars from this subgroup, the Schroeder Uzbek Research Institute of Fruit Growing, Viticulture, and Wine Production (formerly known as the Schroeder Institute), Tashkent Provence, Uzbekistan, recommended Kursadik and Rukhi djuvanon miona for cultivation in the Ferhgana valley and other regions of Central Asia (Mirzaev, 2000; Mirzaev et al., 2004).

Shakhrisabz subgroup. This subgroup spans the foothills and mountainous areas of the Kashka Darya River Valley in the Shakhrisabz and Kitab regions of Uzbekistan (Fig. 1, nos. 17 and 18, respectively). In these areas, apricots are grown at elevations up to $2000 \mathrm{~m}$ above sea level. In the lower elevation of the valleys, precipitation averages 200 to $300 \mathrm{~mm}$ per year. At 1000 to $2000 \mathrm{~m}$ above sea level, the annual precipitation is 400 to $800 \mathrm{~mm}$ (Babushkin, 1963). In the valley, soils are typically of the light sierozem type, although with increasing elevation, soils become light brown to brown soil types.

In general, the apricots of this subgroup are characterized as having small or midsized fruit with light-colored flesh and a large seed with a bitter kernel. Glabrous types can also be found in this subgroup. Typical cultivars of the subgroup are generally described as having exceptional flavor (good sugar to acid ratio) and can be used both fresh and dried (Mirzaev, 2000). It should be noted that orchard production has been based on seedling trees here more so than in the other subgroups (Mirzaev and Kuznetsov, 1984).

Khorezm subgroup. This subgroup is found in the northern part of Uzbekistan [Khorezm Province (Fig. 1, no. 19) and the Karakalpakstan Autonomous Republic] and the Dassoguz (Tashauz) Province of Turkmenistan (Fig. 1, no. 20). The climate of this area is sharply continental and is characterized by having an average annual precipitation of less than $100 \mathrm{~mm}$ along with relative air humidity levels that can occasionally drop to $1 \%$ to $2 \%$. The dry season typically lasts from the end of May to October. The yearly number of frost-free days in this region fluctuates from 180 to 195 (Babushkin, 1963). Summer temperatures can reach $45^{\circ} \mathrm{C}$, whereas winter temperatures often drop below $-30{ }^{\circ} \mathrm{C}$ with a mean yearly temperature of 10 to $12{ }^{\circ} \mathrm{C}$. Winter typically lasts nearly 5 months (Akhmedov, 1993). The main soil type in this region is an alluvial meadow-type soil that is highly saline (total salt content greater than $1.0 \%$, chlorine greater than $0.20 \%$ of ADS). The groundwater is also salty, and the water table is located 1 to $2 \mathrm{~m}$ below the surface (Pankov, 1965).

Apricots of this subgroup are characterized by superior salt, cold, and heat tolerance when compared with other subgroups, but in 


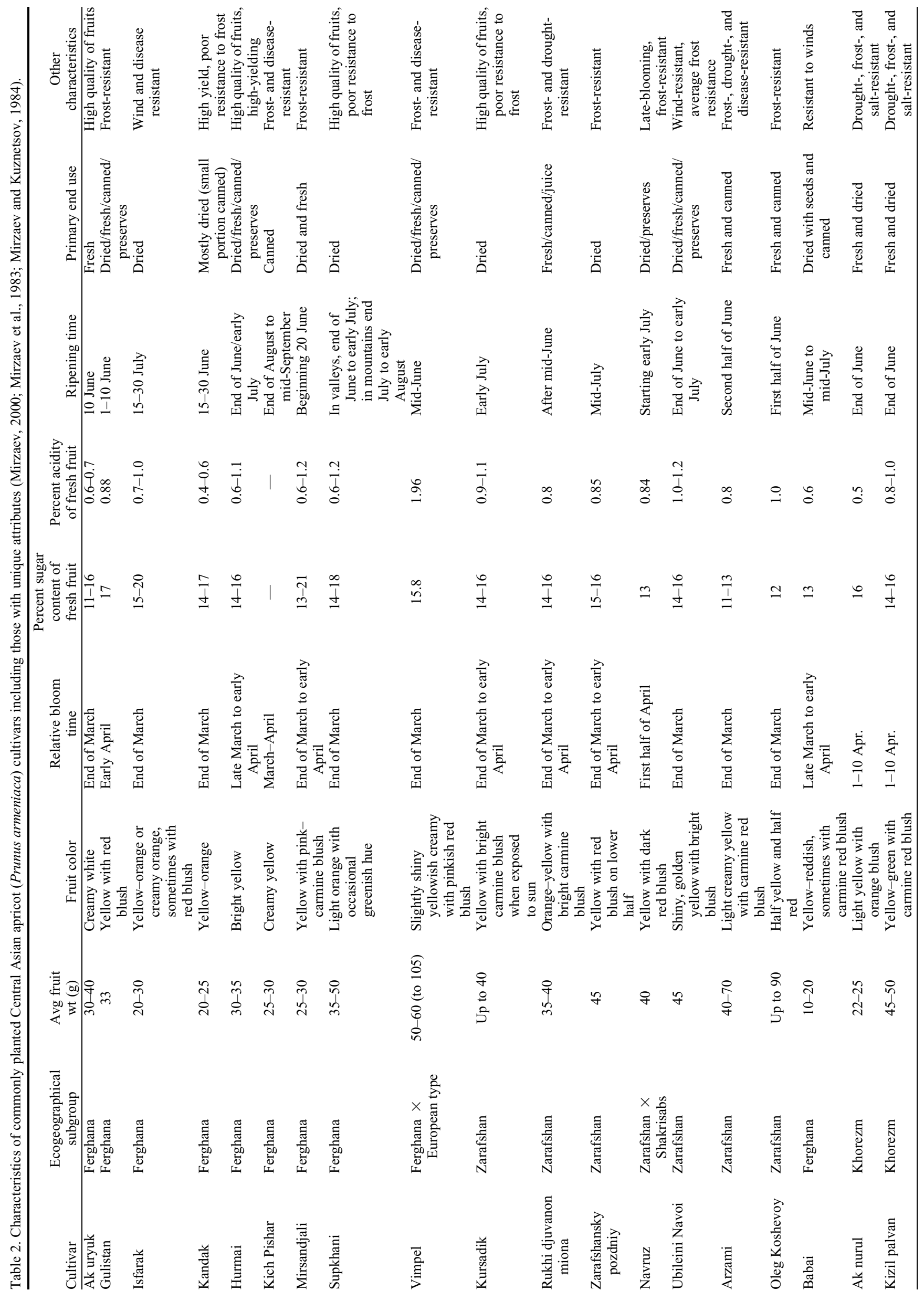

HortScience Vol. 48(6) June 2013 
general, they have small fruits and less variation in fruit characteristics like shape and color. Old orchards of this subgroup include a high percentage of trees grown from seed. The best, most widely grown cultivars of the subgroup are Kizil nukul, Ak nukul, Kizil palvan, Kuzgi, Khorezmi, and Paivandi turtkulsky (Kuznetsov, 1970; Mirzaev, 2000; Mirzaev and Kuznetsov, 1984).

Kopet-Dag subgroup. This small subgroup is found in the upper Sumbar River Basin at an elevation of 500 to $700 \mathrm{~m}$ above sea level in the west part of the Kopet-Dag Range, Turkmenistan (Fig. 1, no. 21). The climate is sharply continental and the relative air humidity is very low as a result of its close proximity to the deserts of Central Asia and Iran. The yearly precipitation ranges from 120 to $150 \mathrm{~mm}$ in the foothills and below and up to 500 to $550 \mathrm{~mm}$ in the higher elevations. Soil is classified as typical sierozem with $1.5 \%$ to $2.5 \%$ organic matter and is non-saline to slightly saline (Fet and Atamuradov, 1994; Gvozdetskiy and Mikhailov, 1978; Pankov, 1965).

The trees of this subgroup are large and relatively long-lived and share traits (general shape of the tree and fruits) in common with the Armenian, semidomesticated apricots known as "Khardzhi" of the Irano-Caucasian group (Kostina, 1964). In general, the fruits are large with bitter kernels and are produced for fresh consumption.

Other ecogeographical groups cultivated in Central Asia. Apricot germplasm from the European ecogeographical group was introduced into Central Asia in the mid-19th century for the purpose of producing fruits for canning. This group is considered to have the least genetic diversity and be the most recent evolutionary derivation of the groups (Kostina, 1970). This group originated from germplasm brought to Europe from Iran, Armenia, and the Middle East and was developed in areas of southern Europe that have more moderate conditions and higher air humidity than Central Asia. The trees in this group are mostly self-compatible and, when compared with the Central Asian group, are less vigorous, have thicker branches and a shorter life expectancy, and are generally less tolerant of wind, heat, drought, and cold. They also have better resistance to fungal diseases, ripen earlier, have a shorter dormancy period, and break bud faster in the spring. The fruits of the European group are generally large (from 40 to $100 \mathrm{~g}$ ), yellow to orange in color, and have bitter kernels. They tend to have a lower sugar content $(6 \%$ to $12 \%)$, are more acidic, and ripen earlier than those of the Central Asian group (Layne et al., 1996; Maghuly et al., 2005; Mirzaev, 2000; Mirzaev and Kuznetsov, 1984; Mirzaev et al., 1983). The widely grown cultivars Vengersky luchshiy, Krasnoshcheky, Korolevsky, Vimpel, and Komsomolets (the latter two were developed by Kostina) are used primarily for canning. 'Zaraya Vostoka', also developed by Kostina, is reported by Mirzaev et al. (1983) to have the most flavorful fruits in the European group. It is commonly cultivated in Turkmenistan (Vazhov et al., 1989).
The cultivars of the Irano-Caucasian group in Central Asia were shown to be very earlyflowering and have low frost resistance. As such, they can only be found in collections of the various scientific organizations in Central Asia (Mirzaev, 2000). The Dzhungar-Zaili subgroup is comprised of landraces and locally cultivated forms and has undergone very limited controlled breeding. This subgroup is characterized by its cold-hardiness, necessary in a region where the winter temperatures reach as low as $-30{ }^{\circ} \mathrm{C}$ (Kostina, 1970). The Dzhungar-Zaili subgroup is grown in the Almaty Province of Kazakhstan and into the Xinjiang region of northwestern China (Fig. 1, nos. 6 and 22).

Production in the Issyk Kul Basin. Although apricots are cultivated in the southern portion of Kyrgyzstan (Osh Province), the northern parts of the country have harsher climatic conditions, limiting their cultivation potential. However, extensive trials have been conducted in the moderated Issyk Kul region (Fig. 1, no. 23). Within the Issyk Kul Basin (elevation of 1600 to $1800 \mathrm{~m}$ ), there is very low precipitation, 158 frost-free days, and an average yearly temperature of $7{ }^{\circ} \mathrm{C}$. With the addition of irrigation, apricot production has been successful in this area using cultivars originating from a variety of Central Asia subgroups and the European ecogeographical group (Arakelyan and Bashmakov, 1981).

\section{Morphology and Biology of $P$. armeniaca in Central Asia}

In Central Asia, cultivated apricot trees have a mature height of 6 to $14 \mathrm{~m}$ (occasionally up to $23 \mathrm{~m}$ ) with trunk diameters of 30 to $60 \mathrm{~cm}$ or greater. The crowns are generally rounded or gently spreading, and root systems consist of a deep tap root with many lateral branches. Interestingly, some cultivars of the Central Asian ecogeographical group (in particular those of the Hurmai and Mirsandjali sortotypes) have been shown to have greater total leaf surface area per tree than the European and Irano-Caucasian groups (Mirzaev and Kuznetsov, 1984). Fruits can reach 2.5 to $5 \mathrm{~cm}$ in length, and the weight of cultivated fruits can vary from 5.5 to $80 \mathrm{~g}$. The color of the fruit varies from white or yellow to orange or orange-red and the kernels can be bitter (inedible) or sweet (edible). Skin of the fruit can vary from pubescent to glabrous with various shades and degrees of orange to red overcolor.

Apricot trees typically have a life span of 30 to 40 years, although some may reach up to 200 years. The average life expectancy of Central Asian cultivars growing on the plains and lower foothills is 50 to 70 years. In the upper foothills and in the mountain zone, the trees tend to be larger and have bigger leaves than those growing at lower elevations. In the mountains of the Chatkal Range, the cultivar Hurmai can often live to an age of 100 to 150 years (Mirzaev and Kuznetsov, 1984). In general, apricot trees start producing fruit at 3 to 4 years when grafted and 4 to 5 years when grown from seed. Depending on the cultivar, the average yield is generally 10 to $15 \mathrm{t} \cdot \mathrm{ha}^{-1}$ (Mavlyanova et al., 2005; Mirzaev et al., 2004). The average productivity of a cultivated apricot is 80 to $100 \mathrm{~kg}$ per tree, but exceptional trees can yield 500 to $600 \mathrm{~kg}$ with some reports of up $1100 \mathrm{~kg}$ per tree (Pulatov, 1976).

According to research conducted at the Schroeder Institute, apricot has a high light requirement and as a result requires open spacing in cultivation with minimum accumulation of 2500 degree-days to mature crops (Mirzaev, 2000). When trees are not spaced properly, there is a higher occurrence of fungal diseases as well as a decrease in yield and fruit quality. In the wild, disease occurs more frequently on trees growing in depressions and wet areas. Apricot requires well-aerated soils and will not thrive in heavy soils with high clay content (Smykov et al., 1985). However, they are considered to be highly tolerant of drought and low relative air humidity (Torrecillas et al., 1999).

Across Central Asia, flowering time fluctuates from year to year and by geographic region. For example, in southern Uzbekistan [Dinau, Surkhandaryo Province (Fig. 1, no. 24)], flowering starts $\approx 6$ Mar., whereas in the north [Chimbay, Karakalpakstan Autonomous Republic (Fig. 1, no. 25)], flowering begins $\approx 10$ Apr. (Mirzaev and Kuznetsov, 1984). Lomakin (1977) reported that, in general, Central Asian cultivars had a higher chilling requirement compared with European cultivars. They also required a higher temperature to initiate blooming in the spring in addition to having slower flower development, typically resulting in an extended period of bloom. Lomakin (1977) also reported that the Central Asian cultivars nearly stopped flower development and progression when temperatures dropped to $8{ }^{\circ} \mathrm{C}$, whereas the European cultivars kept progressing, which made the European cultivars more prone to frost damage. The Central Asian cultivars also tended to better resist dormancy interruption when exposed to warm days during the winter period.

Because the Central Asian group is known to be mostly self-incompatible, studies have been conducted to determine the best cultivars to serve as pollinators for well-known production cultivars. Nearly all cultivars tested exhibited good fruit production when pollinated by 'Arzami' and 'Kursadik', whereas 'Supkhani' and 'Isfarak' successfully pollinated approximately half of the cultivars studied (Mirzaev, 2000; Mirzaev and Kuznetsov, 1984). The Schroeder Institute has recommended a planting regime of 3- to 10-ha blocks composed of six to 10 rows of the main cultivar alternating with one to two rows of a pollinator cultivar.

\section{Plum Pox Virus}

Sharka disease caused by the Plum pox virus (PPV) is a major limiting factor of apricot production in a number of countries and quarantine regulations are necessary to prevent its spread to new regions (Levy et al., 
2000). It is vital that new introductions of germplasm are free of this virus. Primarily as a result of the potential import of PPV, the U.S. Department of Agriculture has listed Prunus as a prohibited genus, which may only be imported into the United States after issuance of a written permit by the Plant Protection and Quarantine Program. Some studies on PPV showed that resistant cultivars from North America contained unique alleles attributed to Central Asian ancestry (Badenes et al., 1996; Hormoza, 2002; Hurtado et al., 2002a, 2002b).

More recently, Zhebentyayeva et al. (2008) conducted extensive amplified fragment length polymorphism and SSR studies using plant material representing North American, European, Central Asian, and Asian (Chinese) apricot germplasm as well as the closely related Prunus species from Asia. Their analyses supported an alternative hypothesis for the origin of PPV resistance in North American cultivars. They concluded that resistance came from introgression of Chinese germplasm as well as possible introgression of the Prunus species P. mandshurica (Maxim.) Koehne, $P$. sibirica var. davidiana (Carrière) Y.L. Chou, and P. mume Siebold \& Zucc. To date, PPV has not been reported in Central Asia with the exception of southeastern Kazakhstan. Spiegel et al. (2004) tested trees including wild apricot (originating from wild populations in Zailiyski Alatou at the northern edge of the Tian Shan Mountain System) and cultivated plum growing in the Pomological Garden in Talgar, Kazakhstan. Although PPV strain D was detected in both plum and apricot trees there, it was reported that the plum displayed severe leaf symptoms, whereas only a single apricot tree showed obvious symptoms. Uzbekistan, Tajikistan, Kyrgyzstan, and Turkmenistan still appear to be free of the virus (S. Kozubaev, Chief of the Uzbek Quarantine Inspection of the Ministry of Agriculture and Water Resources of the Republic of Uzbekistan, personal communication).

\section{Research and Germplasm Holdings of $P$. armeniaca in Central Asia}

Although the most intensive and productive research and breeding of apricot in Uzbekistan was done in the past, work is still being conducted at the Uzbek Scientific Research Institute of Plant Industry, formerly known as the Uzbekistan branch of the Vavilov Research Institute of Plant Industry (VIR) (Tashkent Province, Uzbekistan) and the Schroeder Uzbek Research Institute of Fruit Growing, Viticulture, and Wine Production (Tashkent Province, Uzbekistan) (Mirzaev et al., 2004). Since 1928, the Uzbek Scientific Research Institute of Plant Industry has maintained a living collection of 650 apricot cultivars originating from different geographical regions (Mavlyanova et al., 2005; Smirnova, 1980). The internationally recognized breeder K.F. Kostina worked at this institute in the late 1920s and early 1930s. Over the past century, the institute has released a number of apricot cultivars, including Vimpel, Zaraya
Vostoka, Komsomolets, Spitak kremovii, Hurmai rannii, Gevandi, and Oranjevii pozdnii 263 (Mavlyanova et al., 2005). 'Vimpel' continues to be widely grown in home gardens across suitable growing zones in Central Asia.

The Schroeder Uzbek Research Institute of Fruit Growing, Viticulture, and Wine Production maintains an extensive living collection of more than 500 accessions of apricots, including cultivars and wild forms (Esenbaev et al., 1981; Mirzaev et al., 2004). In 1930, a systematic and comprehensive apricot breeding program was initiated at the institute. Early evaluations identified three Uzbek cultivars (Kursadik, Arzami, Ruhi dzhuvanon miona) and two European cultivars (Krasnoshoki and Korolevski) as being better adapted to the widely fluctuating climatic conditions common in Uzbekistan. These cultivars exhibited flowers and young fruits that were tolerant of late spring frosts (Kovalev, 1963). Schroeder Institute plant breeders subsequently developed improved cultivars expressing traits of later flowering and frost tolerance combined with high fruit quality by selecting improved seedlings from hybrids between local landraces and the larger-fruited European cultivars. The cultivars developed and released include Samarqandski ranniy, Medoviy, Uzbekistansky, Ubileini Navoi, Samarqandskiy \#117, and Zarafshansky pozdniy (Mirzaev et al., 1983; Mirzaev and Kuznetsov, 1984). The cultivar Ubeleini Navoi (Table 2), which originated from a cross between 'Arzami' (Central Asian Zarafshan subgroup) and 'Falgarsky gulungi' (from Tajikistan), has a reputation for high fruit quality and yield (Mirzaev et al., 1983).

Although many of the first cultivars developed displayed flower bud resistance to cold, they did not produce consistently acceptable yields. Further breeding work yielded improved cultivars, including Gulistan (Table 2), Avicena, Abadi, Nuravshon, and Mohir, which had higher chilling requirements and were later blooming than previous cultivars (Mirzaev, 2000; Mirzaev et al., 2004; Mirzaev and Kuznetsov, 1984; Turakulov, 1993). They possessed greater resistance to frost and consistently acceptable fruit yields with their first bloom being at least 1 week later than 'Ubeileini Navoi' and 'Kursadik' (Mirzaev, 2000; Mirzaev et al., 2004). In 2010, the Uzbek Ministry of Agriculture included the cultivars Vimpel, Komsomolets, Gulistan, Navruz, Sovetsky, and Marokand in their recommendations for apricot cultivation in Uzbekistan.

In Tajikistan, apricot research was primarily conducted at the Tajik Scientific Research Institute of Orchards and Viticulture, named after I.V. Michurin (Khujand Province). The institute was renamed and is presently called the Scientific Research Institute of Fruit Growing, Viticulture, and Vegetable Production of the Tajik Agricultural Academy of Science. From 1932 to 1958 , over 250 cultivars from the western part of the Soviet Union (European ecogeographical group) were evaluated. Studies showed that the introduced cultivars underperformed when compared with the local cultivars in terms of yield, fruit quality, level of soluble solids, and cropping consistency (Usmanov, 1983). The most recent reports suggest that $\approx 180$ cultivars are held in their collection today (Progress Report of National Coordinators of Plant Genetic Resources in Central Asia and the Caucasus, 2007).

In Kyrgyzstan, apricot research is currently being conducted at the Kyrgyz Agricultural Research Institute, Bishkek. Apricot research began there in 1937, when it was known as the Kyrgyz Fruit Experiment Station. Later, this station was incorporated into the Kyrgyz Agriculture Research Institute, also in Bishkek, where the apricot program was placed under the direction of S.G. Abdrakhmanov. He crossed cultivars from the Ferghana subgroup such as Arzami, Ahrori, Mirsandjali, and Hurmai krasnii, with cultivars from the European ecogeographical group, including Korolevsky, Krasnosheky, Ananasnii, Vengersky luchshiy, Ranniy krasnii, Komsomolets as well as from the Irano-Caucasian ecogeographical group, including Abdukhaliki, Abdutalibi, and others. The most notable of the 10 cultivars released from the program are Frunzensky ananasnii, Hurmai frunzensky, Hurmai gornii, and Komsomsmolets Kirgizii (Abdrakhmanov, 1969; Soldatov and Kuliev, 2010).

In the 1930s, additional research and breeding of apricot was conducted at the Botanical Garden of the National Academy of Kyrgyzstan, Bishkek, Kyrgyzstan, under the direction of Dr. E.Z. Gareev (1959). $\mathrm{He}$ organized the collection and establishment of over 200 seedling accessions from Uzbekistan, Tajikistan, and the European subgroup. From these plants, he released 16 cultivars for use in both the fresh and dried fruit markets (Soldatov and Kuliev, 2010). Dr. Gareev also began hybridization efforts between the Central Asian and European subgroups, which were continued by Dr. I.V. Soldatov. Dr. Soldatov released three cultivars, the most notable being Kirbotsad, a large-fruited, late-flowering, consistent annual fruit producer (Soldatov and Kuliev, 2010). An additional program was developed with the goal of producing hybrids between apricot and plum ( $P$. domestica) (Soldatov and Kostritsina, 2002; Soldatov and Kuliev, 2010). It resulted in the development of 25 promising hybrids from diverse germplasm, which were found to be well adapted to environmental conditions found in Kyrgyzstan. These hybrids are currently maintained in the collection of the Gareev Botanical Garden. As of 2008, five cultivars (Korolevsky, Krasnoshchoky, Nikitsky, Spitak kremovii, and Effect) were recommended for growers in the northern regions of Kyrgyzstan and eight cultivars (Arzami, Isfarak, Kursadik, Krasnoshchoky, Mirsandjali, Sovetsky, Supkhani, and Hurmai) for the southern areas (State Commission for Variety Testing of Crops, 2008).

In the $1930 \mathrm{~s}, 42$ cultivars were introduced to the VIR Central Experiment Station (at Kara Kala) in Turkmenistan from the Nikita Botanical Garden, the Uzbekistan VIR, and the Maykop, Russia, VIR. This early collection 
also included Uzbekistan, Tajikistan, Azerbaijan, and local Turkmen cultivars. By 1987, the collection was expanded to include 556 accessions introduced from Iran, Syria, Tunisia, Spain, Italy, France, and the United States as well as from the Ferghana, Zarafshan, and Khorezm Central Asian subgroups and other material from the Caucasus, China, Syria, and eastern Europe (Nosulchak et al., 1988). From the Turkmenistan program, 17 cultivars were released with four recommended for growers. These cultivars included Zaraya Vostoka and Komsomolets (developed by Kostina), Konservniy pozdniy (selected from seedlings of the local landraces), and Spitak kremovii (Vazhov et al., 1989). The current status of the Turkmenistan program is unknown.

\section{Central Asian Apricot in the United States}

California is the largest producer of apricots in the United States, producing 56,744 t in 2011 , roughly $94 \%$ of the U.S. total crop [U.S. Department of Agriculture (USDA) National Agricultural Statistics Service, 2012a], which was less than $2 \%$ of the world crop [3,834,475 $\mathrm{t}$ in 2011 (FAO, 2013)]. Washington is the second largest producer in the United States with $3538 \mathrm{t}$ in 2011 and Utah is third with 181 t. No other states record any appreciable production. Based on the annual production reported by the USDA's Fruit and Tree Nuts Situation and Outlook Yearbook 2011 (USDA, 2012b), U.S. apricot production in 2011(60,460 t) has been reduced by nearly $50 \%$ since $1980(120,000 \mathrm{t})$.

Some efforts in incorporating Central Asian apricot germplasm into U.S. breeding programs have been made in California by USDA breeders. Beginning in the early 1990s, when access to the countries of the former USSR became available, accessions from across Central Asia were imported to California in an effort to improve the sugar profiles and overall quality and diversity of California apricots (Ledbetter, 2009). On their own, fruits from the introduced Central Asian germplasm were believed to be too small to be sold directly in the United States. However, some of the Central Asian varieties and seedling selections were found to express important traits, like elevated Brix levels, varied sugar profiles, later maturation dates, and interesting morphological characteristics that were lacking in current U.S. germplasm holdings.

Breeders were able to produce fruiting California $\times$ Central Asia $F_{1}$ hybrids starting in 1997. These hybrid seedlings, as expected, showed great variability. Unfortunately, fruit size was still not large enough for fresh sale, although many of the offspring showed segregation for multiple desired traits. Thus, select $F_{1}$ plants were subsequently intercrossed or backcrossed to improved California cultivars (Ledbetter et al., 2006). Through these efforts, breeders were able to produce many progeny expressing desired traits from both parents. These plants included selections that ripen over 2 weeks later than standard Californian cultivars, plants with highly elevated Brix levels, and plants that produce glabrous-skinned fruits from their Central Asian donor, all with acceptable fruit size (Ledbetter, 2009). Commercial production trials are currently ongoing for several Central Asian-related selections to determine their suitability for release and production.

The USDA presently holds a number of accessions and cultivars from Central Asia in its Germplasm Resource Information Network (GRIN) National Germplasm Repository holding at the University of CaliforniaDavis (GRIN, 2013). Many of these were donated by institutes from the former USSR and from collection trips undertaken by various apricot breeders, collectors, and scientists. Based on apricot germplasm from Central Asia and other regions, it is clear that significant improvements can be made in the crop, and efforts are already being made. However, public breeding programs for apricots in the United States are limited to the USDA at Parlier, CA, and Rutgers University, New Brunswick, NJ.

The principal objective of the Rutgers University/New Jersey Agricultural Experimental Station (NJAES) apricot breeding program is to develop high-quality cultivars that will be consistently productive in the northeastern United States. The NJAES apricot breeding program was initiated in the mid1950s (Hough and Bailey, 1982). Very early in the program it was recognized that apricots from the European group were poorly adapted to New Jersey conditions. The climate of New Jersey (and the northeastern United States) can often cause serious difficulties in apricot culture (Table 3). Chilling requirements of some cultivars are often met by the end of December, whereas extreme fluctuations in winter weather can cause temperatures to rise as high as $20^{\circ} \mathrm{C}$ and fall as low as $-20^{\circ} \mathrm{C}$ within a short period of time. Exposure to this type of heating and cooling can cause trees to lose their winterhardiness and often results in severe damage to the trunk of the trees. Additionally, late spring frosts commonly occur and can damage flower buds, flowers, and even immature fruit. Finally, spring in the northeastern United States is often quite humid and rainy, increasing disease pressure. To address these issues, breeding efforts have focused on increasing both chilling requirements and post-rest heat requirements necessary to induce blooming and enhancing the level of disease resistance. To expand the fresh apricot season, trees exhibiting early and late maturation were identified and used in controlled cross hybridizations. In addition to developing trees with beneficial phenological traits, the program also selects for increased fruit quality, size, and sugar content as well as unique skin color, flesh firmness and juiciness, stone freeness, and extended shelf life. Pollen from Central Asian cultivars was obtained from cooperators in the early 1960s through the early 1970s and was regularly used in crosses. Since the program's inception, six cultivars have been released, including OrangeRed $^{\mathrm{TM}}$ ('Bhart', tested as NJA32), Early Blush $^{\mathrm{TM}}$ ('NJA53'), and Sugar Pearls ${ }^{\mathrm{TM}}$ ('NJA150'), all of which contain Central Asian heritage. Today, nearly all of the crosses made at the NJAES have at least one parent that was derived, in part, from Central Asian germplasm.

From 1997 to 1999, a large-scale germplasm collection effort was initiated at Rutgers University to enhance the existing apricot breeding program. Authors David Zaurov and Joseph Goffreda collected openpollinated apricot seeds representing germplasm from a wide area of Central Asia with a focus on Uzbekistan and Kyrgyzstan. Seeds were gathered from the germplasm collections of research institutes (Schroder Institute, Research Institute of Plant Industry, Experiment Station of Tashkent Agrarian University, Kyrgyz Research Agricultural Institute, and Gareev Botanical Garden), where the germplasm collections also contained selections from around Central Asia as well as backyard gardens and local markets. A total of 285 seed lots were collected with each seed lot consisting of 25 to 100 seeds. Additionally, scion wood of specific cultivars was received from two major germplasm repositories, the tree fruit repository at the Central Asian Experiment Station of the Institute of Plant Industry (formerly a branch of VIR), and the Schroeder Institute. Both sites are located near Tashkent, Uzbekistan. By 2001, the Rutgers University Fruit Research and Extension Center, Cream Ridge, NJ, housed a collection of more than 10,000 Central Asian apricot trees, mostly derived from open-pollinated seed, in addition to the clonal selections. Over the next 10 years these trees were grown in the field at Cream Ridge and were systematically evaluated for characteristics important to the Rutgers breeding program. Because of the large number of seedlings, the initial spacing was restricted to less than $1 \mathrm{~m}$ between each plant in the row. Each year, poor-performing trees were systematically culled with many others dying on their own from lack of adaptation and/or disease. As of

Table 3. Climate information from weather stations near the Rutgers University Cream Ridge Fruit Research and Extension Center (Freehold, NJ) and the Improving Perennial Plants for Food and Bioenergy, Inc. research farms (Logan, UT) (National Climate Data Center, 2013a, 2013b) in comparison with the Samarqand and Pskem regions of Tashkent Province, Uzbekistan (Mirzaev, 1982).

\begin{tabular}{|c|c|c|c|c|c|c|}
\hline & \multirow{2}{*}{$\begin{array}{c}\text { Avg yearly } \\
\text { precipitation }(\mathrm{mm})\end{array}$} & \multicolumn{2}{|c|}{ Record air temp $\left({ }^{\circ} \mathrm{C}\right)$} & \multirow{2}{*}{$\begin{array}{l}\text { Avg yearly } \\
\text { temp }\left({ }^{\circ} \mathrm{C}\right)\end{array}$} & \multicolumn{2}{|c|}{ Avg air temp $\left({ }^{\circ} \mathrm{C}\right)$} \\
\hline & & Maximum & $\overline{\text { Minimum }}$ & & January & July \\
\hline Freehold, NJ & 1187 & 41.1 & -28.9 & 11.4 & -1.1 & 23.5 \\
\hline Logan, UT & 477 & 39.4 & -33.3 & 7.4 & -6.1 & 22.7 \\
\hline Samarqand, Uzb. & 328 & 40.0 & -30.0 & 12.9 & -2.0 & 24.0 \\
\hline Pskem, Uzb. & 995 & 41.0 & -27.0 & 8.9 & -1.8 & 23.3 \\
\hline
\end{tabular}


2013, only 160 trees remain, representing the most disease-resistant and productive trees that produce high-quality fruits. Phenological and fruit characteristics of some promising Central Asian apricot selections growing at Cream Ridge are presented in Table 4, and images of general fruit diversity are presented in Figure 2.

Although Utah currently has a small amount of commercial apricot production, spring frosts during flowering can often damage crops and limit production. Currently, the common cultivars grown in Utah include

Table 4. Fruit characteristics of select Central Asian apricots accessions growing at the Rutgers University Cream Ridge Fruit Research Station, Cream Ridge, NJ.

\begin{tabular}{lcccccc}
\hline Genotype no. & $\begin{array}{c}\text { Avg ripening } \\
\text { date }\end{array}$ & $\begin{array}{c}\text { Avg } \\
\text { wt (g) }\end{array}$ & $\begin{array}{c}\text { Avg flesh } \\
\text { firmness }^{z}\end{array}$ & $\begin{array}{c}\text { Avg fruit } \\
\text { quality }^{z}\end{array}$ & $\begin{array}{c}\text { Avg percent } \\
\text { soluble solids }\end{array}$ & $\begin{array}{c}\text { Avg } \\
\text { crop load }^{z}\end{array}$ \\
\hline K22-227-98629 & 11 July & 39.8 & 3.5 & 3.8 & 20.0 & 3.1 \\
D79-51-98635 & 8 July & 32.7 & 3.0 & 3.6 & 18.0 & 4.9 \\
D80-57-98649 & 10 July & 55.0 & 3.0 & 3.0 & 17.0 & 3.8 \\
D80-50-98649 & 22 June & 56.0 & 2.8 & 3.0 & 11.0 & 4.3 \\
D80-56-98649 & 6 July & 58.5 & 2.8 & 3.8 & 13.0 & 3.0 \\
K23-266-98651 & 18 July & 24.0 & 3.0 & 3.0 & 22.0 & 4.0 \\
K23-268-98651 & 16 July & 33.0 & 3.5 & 3.0 & 23.0 & 3.8 \\
DW2-100-99992 & 24 June & 29.0 & 2.5 & - & 21.0 & 4.5 \\
DT7-367-98812 & 5 July & 62.0 & 3.0 & 3.5 & 16.0 & 2.8 \\
\hline
\end{tabular}

${ }^{\mathrm{z}}$ From 1 to $5 ; 5$ is the best.

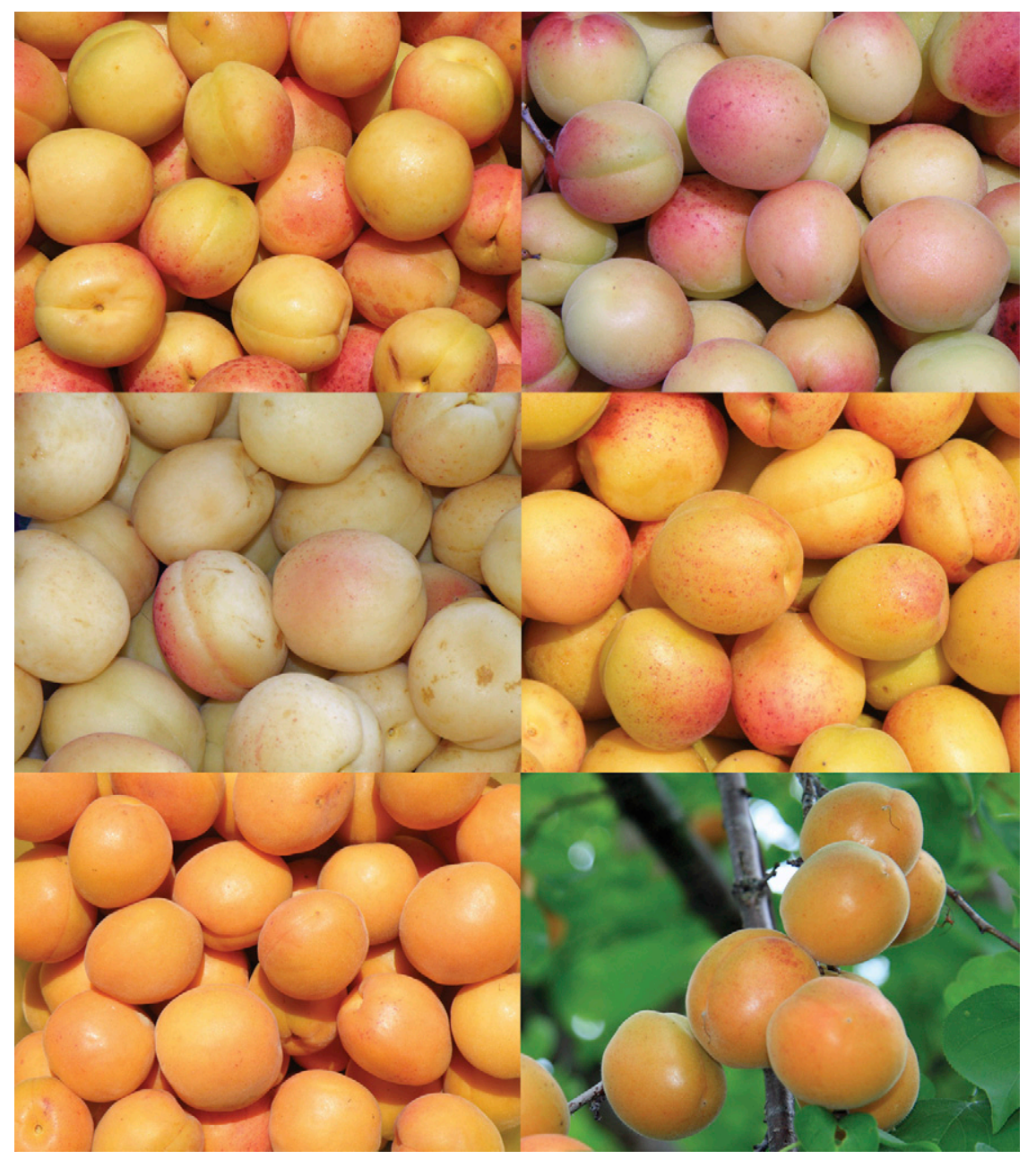

Fig. 2. Example of fruit diversity from Central Asian trees growing at the Rutgers University Fruit Research Station, Cream Ridge, NJ. Accession numbers are as follows, clockwise from upper left: DT3-348; D85 - 47; DT4 - 306; unspecified fruit on tree; DT10-327; DT3-349. collected in Central Asia and/or through seedlings derived from Central Asian-related advanced selections from Rutgers University. The breeding goals in Utah are similar to those of New Jersey; in addition, the material is screened for resistance to lime-induced iron chlorosis and tolerance of high $\mathrm{pH}$ soils as well as saline soils and irrigation water. They are also assessed for the presence of edible kernels, tolerance of cold temperatures during flowering and drought, and improved rootstock performance. These characteristics have all been observed in the Central Asian material with tree health of a number of seed selections representing a significant improvement over current cultivars used in the region. Furthermore, the most promising Central Asian seedlings have been crossed with improved breeding selections from Rutgers University with progeny now undergoing evaluation in Thatcher and Hyde Park, UT. The overall goal is to improve reliability and consistency of crop yields in the region in addition to higher fruit quality, which should support an expansion of the industry as well as edible landscapes in Utah.

\section{Conclusions}

Apricot germplasm from Central Asia has many unique and useful characteristics such as a diversity of fruit flavors with high sugar content and extreme cold, drought, heat, and salt tolerance. These traits are very valuable to the future genetic improvement and wider use of the species. The breeding value of the Central Asian group has been demonstrated in the work of Ledbetter et al. (2006) with dramatic increases in the sugar content and fruit quality of California-adapted apricot varieties. Furthermore, the last six releases from the Rutgers University NJAES program each contain an appreciable amount of Central Asian germplasm in their pedigrees. More recently, by making a wide germplasm collection in Central Asian, well-adapted seedlings were identified that produce very high-quality, high sugar content, flavorful fruit of marketable size and yield (Table 4). Continued germplasm exploration and evaluation would likely lead to the identification of additional improved material, which could ultimately lead to the expanded production of this high-value crop.

Although access to Central Asia is increasing, loss of habitat and lack of regeneration of native populations resulting from human development and overgrazing, compounded by challenging economic times, is putting pressure on the existing in situ and ex situ pools of apricot genetic resources. Our article aims to shed light on these valuable resources to promote their improved use, management, and preservation. Increased study and introduction of $P$. armeniaca from the genetically diverse wild and cultivated germplasm found in Central Asia will facilitate the development of new cultivars with improved fruit characteristics. Traits such as high sugar content, elevated Brix levels, unique flavor and aroma, edible kernels, and disease resistance will be 
valuable for breeders working to develop trees with high quality fruit while helping to decrease vulnerability to existing and emerging pests and diseases. Additionally, germplasm with local adaptations to the diverse climactic conditions of Central Asia could potentially be the source of unique traits that may be used to expand the existing area of apricot production in the United States, including regions where reliable commercial production is currently not possible. Based on its adaptation to extreme environments, apricots from Central Asia may be particularly useful for crop development on degraded, deforested, and marginal land as well as for use in stabilizing soils and preventing erosion. The authors are currently using Central Asian germplasm in both the eastern and Intermountain West regions of the United States with great promise. Through this article we hope to encourage collaboration, cooperation, and the reciprocal exchange of $P$. armeniaca and/or germplasm of other plant species between Central Asian institutions and interested scientists and organizations around the world.

\section{Literature Cited}

Abdrakhmanov, S.G. 1969. Brief results of the selection and breeding of new cultivars of pears and stone fruit crops. Trudy Kirgizskogo nauchno-issledovatel'skogo intituta zemledeliia [Scientific Proceedings of the Kirghiz Research Institute of Agriculture]. 7:141-150. Frunze, Kyrgyzstan [in Russian].

Achkinazi, E.Y. 1933. The apricots of Samarkand region. Trudy Samarkandskoi selektsionnopomologicheskoi opitnoi stantsii [Scientific Proceedings of the Samarkand Pomological Experiment Station]. Vol. 1. Samarkand, Uzbekistan [in Russian].

Akhmedov, E. 1993. Republic of Uzbekistan: Reference book. Uzbekiston Publishing, Tashkent [in Uzbek, English, and Russian].

Andrienko, M.V. 1997. Pomologiia T. 3: Abrikos, persik, alicha [Pomology. Vol. 3: Apricot, peach, plum]. Urozhai Publishing, Kiev [in Russian].

Arakelyan, U.G. and E.A. Bashmakov. 1981. Apricot in the Kyrgyz S.S.R. Part 1. 6th Intl. Symp. on Apricot Culture and Decline, Yerevan, U.S.S.R., 4-8 July 1977. p. 86-87. Ayastan Publishing, Yerevan, Armenia [in Russian].

Babushkin, L.N. 1963. Atlas of the Uzbek S.S.R [Atlas Uzbekskoi SSR]. Akademiya Nauk Uzbekskoi Uz.S.S.R., Tashkent-Moscow, Uzbekistan [in Russian].

Badenes, M.L., M.J. Asins, E.A. Carbanel, and G. Glacer. 1996. Genetic diversity in apricot, Prunus armeniaca, aimed at improving resistance to plum pox virus. Plant Breed. 115:133139.

Bailey, C.H. and L.F. Hough. 1975. Apricots, p. 367-384. In: Janick, J. and J. N. Moore (eds.). Advances in fruit breeding. Purdue Univ. Press, West Lafayette, IN.

Dzhuraev, K. and D.P. Pulatov. 1988. Geografiia Tadzhikistana [Geography of Tajikistan]. Maorif Publishing, Dushanbe [in Russian].

Esenbaev, Z.I., R.A. Safarov, N.G. Gaibov, M.M. Mirzaev, and M.M. Penson. 1981. Orchards of Uzbekiston. Uzbekiston Publishing, Tashkent, Uzbekistan [in Uzbek, Russian, and English].

Fet, V. and K.I. Atamuradov. 1994. Biogeography and ecology of Turkmenistan. Kluwer, Dordrecht, The Netherlands, and Boston, MA.
Food and Agricultural Organization of the United Nations. 2013. Agricultural production, crops primary apricots. 22 Jan. 2013. <http://faostat. fao.org/site/567/default.aspx\#ancor>

Gareev, E.Z. 1959. Plodovye kultury Kirgizstana [Fruit species in Kyrgyzstan]. Kirgosizdat Publishing, Frunze [in Russian].

Germplasm Resource Information Network. 2013. Holdings at Natl. Germplasm RepositoryDavis, California (DAV). Prunus armeniaca. 9 Jan. 2013. <http://www.ars-grin.gov/cgi-bin/ npgs/html/tax_site_acc.pl?DAV\%20Prunus\% 20 armeniaca $>$.

Gvozdetskiy, N.A. and N.I. Mikhailov. 1978 Fizicheskaia geografiia SSSR, Aziatskai chast [Physical geography of the U.S.S.R., Asian part]. Misl Publishing, Moscow [in Russian].

Hormoza, J.I. 2002. Molecular characterization and similarity relationships among apricot (Prunus armeniaca L.) genotypes using simple sequence repeats. Theor. Appl. Genet. 104: 321-328.

Hough, L.F. and C.H. Bailey. 1982. 30 years of apricot breeding in New Jersey. Acta Hort. 121:207-210.

Hurtado, M.A., A.L. Westman, E. Beck, A.G. Abbott, G. Llácer, and M.L. Badenes. 2002a. Genetic diversity in apricot cultivars involved in breeding for sharka resistance based on AFLP marker. Euphytica 127:297-301.

Hurtado, M.A., C. Romero, S. Vilanova, A.G Abbott, G. Llácer, and M.L. Badenes. 2002b. Genetic linkage maps of two apricot cultivars (Prunus armeniaca L.), and mapping of PPV (sharka) resistance. Theor. Appl. Genet. 105: 182-191.

Ivanov, V.F. and A.S. Ivanova. 1981. Apricot salt tolerance in connection with its propagation in dry steppe regions of southern Ukraine. Part 1 , 6th Intl. Symp. on Apricot Culture and Decline, Yerevan, U.S.S.R., 4-8 July 1977, p. 122-126. Ayastan Publishing, Yerevan, Armenia [in Russian].

Kalmikov, C.C. 1973. Dikorastushiye plodoviye zapadnogo Tyan-Shanya i khozyaistvennoye osvoyeniye ikh [Wild fruit species of the western Tian-Shan and their economic development]. Fan Publishing, Tashkent, Uzbekistan [in Russian].

Kolosova, L.N. 1981. Geograficheskii atlas dlya uchutelei srednei shkoli [Geographic atlas for secondary school teachers]. 4th Ed. GUGK Publishing, Moscow, Russia [in Russian].

Korzin, V.V. and V.M. Gorina. 2009. Influence of low air temperatures in winter and spring period on apricots trees in Crimea. Trudy universiteta bioresursov i prirodovedeniya Ukraini. Crimsky Agrotekhnichesky Universitet. [Scientific Proceedings of the Bioresource and Nature of the Ukraine]. Crimean Agrotekhnical University 125:168-172 Simferopol.

Kostina, K.F. 1936. Abrikos. Trudy po Prikladnoi Botanike, Genetike i Selektsii [Apricots. Bulletin of Applied Botany, Genetics and Breeding] Suppl. 83. [in Russian].

Kostina, K.F. 1941. Armeniaca, p. 581-604. In: Komarov, V.L. (ed.). Flora of the U.S.S.R. Izdatel'stvo Akademii Nauk U.S.S.R., MoskvaLeningrad, Russia [in Russian].

Kostina, K.F. 1964. Application of the phytogeographical method for apricot classification. Trudy Nikitskogo Botanicheskogo Sada [Proceedings of the Nikita Botanical Garden] 24. Kolos Publishing, Moscow [in Russian].

Kostina, K.F. 1970. Seletsionnoye ispolzovaniye sortovih fondov abrikosa [Selective utilization of apricot stock], p. 177-189. In: Ayzenberg, V.Y. (ed.). Abrikos. Ayastan, Yerevan [in Russian].
Kostina, K.F. 1978. Apricot breeding under conditions of the U.S.S.R. south. Acta Hort. 85:190194.

Kovalev, N.V. 1963. Abrikos [Apricots]. Kolos Publishing, Moscow, Russia [in Russian].

Kudryashov, S.N. 1950. Plod. Shakrisyabza 1:2. [Fruit species of Shakhrisyabz].

Kuznetsov, V.V. 1970. Kultura abrikosa v Uzbekskoi SSR [Apricot culture in the Uzbek S.S.R.]. Ayastan Publishing, Yerevan, Armenia [in Russian].

Layne, R.E.C., C.H. Bailey, and L.F. Hough. 1996. Apricots, p. 79-111. In: Janick, J. and J.N. Moore (eds.). Fruit breeding, Vol. 1. Tree and tropical fruits. Wiley, New York, NY.

Ledbetter, C., S. Peterson, and J. Jenner. 2006. Modification of sugar profiles in California adapted apricots (Prunus armeniaca L.) through breeding with Central Asian germplasm. Euphytica 148:251-259.

Ledbetter, C.A. 2009. Using Central Asian germplasm to improve fruit quality and enhance diversity in California adapted apricots. Acta Hort. 814:77-80.

Levy, L., V. Damsteegt, R. Scorza, and M. Kolber. 2000. Plum pox potyvirus disease of stone fruits. APSnet Features. doi: 10.1094/APSnetFeature2000-0300. <http://caps.ceris.purdue.edu/webfm_ send/1424>

Lomakin, E.N. 1971. The wild apricot Armeniaca vulgaris Lam., of Central Asia. Trudy po Prikladnoi Botanike, Genetike i Selektsii [Bulletin of botany, genetics and breeding] 45:8995 [in Russian]

Lomakin, E.N. 1977. Genepool of apricots, goals and breeding work in Central Asia, p. 13-22. In: Nauchno-metodicheskoe soveshanie po kulturye abrikosa v Srednei Azii [Scientificmethodological conference on apricot culture], MSKh Uz.S.S.R., Tashkent, Uzbekistan [in Russian].

Maghuly, F., E. Borroto, S. Ruthner, A. Pedryc, and M. Laimer. 2005. Microsatellite variability in apricots (Prunus armeniaca L.) reflects their geographic origin and breeding history. Tree Genet. Genomes 1:151-165.

Mavlyanova, R.F., F.K. Abdullaev, P. Khodjiev, D.E. Zaurov, T.J. Molnar, J.C. Goffreda, T.J. Orton, and C.R. Funk. 2005. Plant genetic resources and scientific activities of the Uzbek Research Institute of Plant Industry. HortScience 40:10-14.

Mehlenbacher, S.A., V. Cociu, and L.F. Hough. 1991. Apricots (Prunus), p. 65-107. In: Moore, J.N. and J.R. Ballington, Jr. (eds.). Genetic resources of temperate fruit and nut crops. Acta Hort 290.

Mirzaev, M.M. 1982. Gornoe sadovodstvo Uzbekistana [Mountain orchards of Uzbekistan]. Fan Publishing, Tashkent, Uzbekistan [in Russian].

Mirzaev, M.M 2000. Abrikos v Uzbekistane [Apricots in Uzbekistan]. Shark Press, Tashkent, Uzbekistan [in Russian].

Mirzaev, M.M., U.M. Djavacynce, D.E. Zaurov, J.C. Goffreda, T.J. Orton, E.G. Remmers, and C.R. Funk. 2004. The Schroeder Institute in Uzbekistan: Breeding and germplasm collections. HortScience 39:917-921.

Mirzaev, M.M and V.V. Kuznetsov. 1984. Abrikos v Uzbekistane: Biologiia, sorta, selektsiia, agrotekhnika [Apricots in Uzbekistan: Biology, cultivars, breeding, agrotechnology]. Fan Publishing, Tashkent, Uzbekistan [in Russian].

Mirzaev, M.M., V.V. Kuznetsov, R.G. Borozdin, A.I. Frolov, S.M. Jivotinskay, A.H. Tabanali, and U.M. Djavacynce. 1983. Pomologiia Uzbekistana [Pomology of Uzbekistan]. Fan Publishing, Tashkent, Uzbekistan [in Russian]. 
National Climate Data Center. 2013a. National Oceanic and Atmospheric Administration, Freehold-Marlboro, NJ, station. 10 Feb. 2013. $<$ http://www.ncdc.noaa.gov/cdo-web/datasets/ ANNUAL/stations/COOP:283181/detail>.

National Climate Data Center. 2013b. National Oceanic and Atmospheric Administration, Logan, Utah State University, Logan, UT, station. 10 Feb. 2013. <http://www.ncdc.noaa. gov/cdo-web/datasets/ANNUAL/stations/COOP: 425186/detail>.

Nosulchak, V.A., O.F. Mizgirova, and G.M. Levin. 1988. Stone fruits, p. 15-17. In: The Turkmen Experiment Station of VIR. Ashkhabad, Turkmenistan [in Russian].

Pankov, M.A. 1965. Soil science, p. 7-79. In: Rizhov, S.N. and I.F. Sukach (eds.). Irrigated agriculture. Uzbekistan Publishing, Tashkent, Uzbekistan [in Russian].

Progress Report of National Coordinators of Plant Genetic Resources in Central Asia and the Caucasus. 10 Mar. 2007, p. 37. Biodiversity International, Tashkent, Uzbekistan.

Pulatov, A. 1976. Tajik apricot. Irfon Publishing, Dushanbe, Tajikistan [in Russian].

Ribakov, A.A. and S.A. Ostroukhova. 1972. Horticulture of Uzbekistan. 3rd Ed. Ukituvchi Publishing, Tashkent, Uzbekistan [in Russian].

Smirnova, V.A. 1980. Abrikos sortotipa Khurmai [Apricot sortotype Khurmai], p. 104-115. In: Mirovye rastitelnye resursy v Srednei Azii [Global plant resources in Central Asia], Vol. 7. Glavnoe upravlenie propagandy i vnedreniia dostizhenii nauki i peredovogo opyta MSKH UzSSR, Tashkent [in Russian].

Smykov, V.K., A.M. Sholokhov, and T.M. Savina. 1985. Metodicheskiye rekomendatsii po podboru sortov abrikosa dlya virashchivaniya $\mathrm{v}$ Krimu [Methodical recommendations on selection of apricot cultivars for growing in Crimea]. All union Agricultural Academy of Science named after V.I. Lenin and Nikita State Botanical Garden, Yalta, Ukraine [in Russian].

Soldatov, I.V. and T.V. Kostritsina. 2002. Rezultatui mezhrodovoi gibridizatsii slivui $\mathrm{s}$ abrikosom [Results of intergeneric hybridization between plum and apricot], p. 136-141. In: Mat. resp. nauchno-praktich. Konf. "Botanicheskiye issledovaniya v Kirgizstanye" [The republican scientific-practical conference in Kyrgyzstan "Botanical research in Kyrgyzstan”] Olimp Publishing, Bishkek, Kyrgyzstan [in Russian].

Soldatov, I.V. and A.S. Kuliev. 2010. Introduction and breeding of the ordinary apricot (Armeniaca vulgaris Lam.) and the black apricot (Armeniaca dasycarpa Ehrh.) in Kyrgyzstan, p. 132-138. In: Soldatov, I.V., et al. (eds.) Introduction and Conservation of the Biodiversity and the Use of Plants: Collection of research papers: Materials of the International Scientific and Practical Conference dedicated to the 100-Anniversary of the Corresponding Member of NAS KR, Prof. E. Gareev and to the International Year of the Biodiversity. Bishkek, Kyrgyzstan. 7-9 Sept. 2010. E. Gareev Bot. Garden of NAS KR, Bishkek [in Russian].

Spiegel, S., E.M. Kovalenko, A. Varga, and D. James. 2004. Detection and partial molecular characterization of two Plum pox virus isolates from plum and wild apricot in southeast Kazakhstan. Plant Dis. 88:973-979.

State Commission for Variety Testing of Crops. 2008. State register of varieties approved for use in the Kyrgyz Republic. Ministry of Ministry of Agriculture, Water and Processing Industry of Kyrgyz Republic, Bishkek, Kyrgyzstan [in Russian].

Torrecillas, A., R. Galego, A. Perez-Pastor, and M.C. Ruiz-Sanchez. 1999. Gas exchange and water relations of young apricot plants under drought conditions. J. Agr. Sci. 132:445-452.

Turakulov, Z.T. 1993. Apricot breeding, p. 10-22. In: Mirzaev, M.M. (ed.). Selektsiia plodovuikh i vinograda V Uzbekistanye [Breeding fruit and grapes in Uzbekistan]. Mehnat Publishing, Tashkent, Uzbekistan [in Russian].

U.S. Department of Agriculture. 2012a. National Agriculture Statistics Service. Quick stats database. 20 June 2012. <http://quickstats.nass. usda.gov/results/AC1EA05F-3440-3072-8AD7132793D14F52>.
U.S. Department of Agriculture. 2012b. Fruit and tree nuts situation and outlook yearbook 2011 . 20 June 2012. <http://www.ers.usda.gov/ publications/fts/Yearbook11/FTS2011.pdf $>$.

Usmanov, U.M. 1983. Apricot culture in North Tajikistan. Acta Hort.121:259-262. 7th Symp. on Apricot Culture and Decline, 16-21 July 1981, Bucharest-Constanta, Romania.

Utah State University. 2013. Apricot varieties. Fruit production. 13 Jan. 2013. < http://extension.usu. edu/carbon/index.cfm/fruit/aprvar>.

Vavilov, N.I. 1931. The wild relatives of fruit trees of the Asian part of the USSR and Caucasus and problems of origin of fruit trees. Bulletin of applied botany, genetics and breeding [Trudy po Prikladnoi Botanike, Genetike i Selektsii] 26:343-360 [in Russian].

Vavilov, N.I. 1951. Phytogeographic basis of plant breeding, p. 13-54. In: The origin, variation, immunity and breeding of cultivated plants: Selected writings of Vavilov, N.I. and F. Verdoon (eds.). Chron. Bot. 13.

Vazhov, V.I., V.F. Ivanov, and A.S. Ivanova. 1989. Abrikos [Apricot]. In: Smykov, V.K. (ed.). Lenin All Union Academy of Agricultural Science, Agropromizdat Publishing, Moscow, Russia [in Russian].

Zhebentyayeva, T., C.A. Ledbetter, L. Burgos, and G. Llácer. 2012. Apricot, p. 415-458. In: Badenes, M.L. and D.H. Byrne (eds.). Fruit breeding, handbook of plant breeding 8. Springer Science+Business Media, New York, NY.

Zhebentyayeva, T.N., G.L. Reighard, V.M. Gorina, and A.G. Abbott. 2003. Simple sequence repeat (SSR) analysis for assessment of genetic variability in apricot germplasm. Theor. Appl. Genet. 106:435-444.

Zhebentyayeva, T.N., G.L. Reighard, D. Lalli, V.M. Gorina, B. Krška, and A.G. Abbott. 2008. Origin of resistance to plum pox virus in Apricot: What new AFLP and targeted SSR data analyses tell. Tree Genet. Genomes 4:403-417.

Zhukovsky, P.M. 1971. Kulturnye rasteniia i ikh sorodichi [Cultivated plant species and their relatives]. 3rd Ed. Kolos, Leningrad, Russia [in Russian]. 